\title{
Nursing consultation software for hypertensive users of the Family Health Strategy
}

\author{
Software para consulta de enfermagem aos hipertensos da Estratégia Saúde na Família \\ Software para consulta de enfermería de los hipertensos en la Estrategia Salud de la Familia
}

\section{Jancelice dos Santos Santana', Maria Miriam Lima da Nóbrega', Jacira dos Santos Oliveira', Maria Júlia Guimarães Oliveira Soares'}

' Universidade Federal da Paraíba, Health Sciences Center. João Pessoa, Paraíba, Brazil.

\section{How to cite this article:}

Santana JS, Nóbrega MML, Oliveira JS, Oliveira MJG. Nursing consultation software for hypertensive users of the Family Health Strategy. Rev Bras Enferm [Internet]. 2018;71(5):2398-403. DOI: http://dx.doi.org/10.1590/0034-7167-2017-0174

Submission: 02-25-2017 Approval: 07-07-2017

\section{ABSTRACT}

Objective: To report the development of a nursing consultation software for hypertensive users of the Family Health Strategy. Method: Applied methodological research based on Roger Pressman's Software Engineering, developed in three cycles: planning, composed of the definition of the database prototyping and modelling; development of the navigation interface; and development of functional expressions and programming. Result: The software consists of administrative and nursing consultation screens. In the history, there is the option of undertaking the first and next consultation; nursing diagnoses are suggested by the system after entering information and can be selected by nurses. Interventions for diagnoses are suggested and can be chosen by nurses after structuring the medical plan. Conclusion: It is believed that the introduction of computer technology for nursing consultation brings several contributions, such as standardization, integration with different information systems, and continuous update.

Descriptors: Nursing; Consultation; Software; Hypertension; Health.

\section{RESUMO}

Objetivo: Relatar o desenvolvimento de um software para consulta de enfermagem aos hipertensos na estratégia saúde da família. Método: Pesquisa metodológica aplicada, baseada na engenharia de software de Pressman, desenvolvida em três ciclos: planejamento, composto pela definição da prototipação e modelagem do banco de dados; desenvolvimento da interface de navegação; e elaboração das expressões funcionais e da programação. Resultado: o software consiste em telas administrativas e telas para a consulta de enfermagem. No histórico, há a opção de realizar a primeira consulta e ou consulta subsequente; os diagnósticos de enfermagem são sugeridos pelo sistema, depois de serem inseridas as informações, e podem ser selecionados pelo enfermeiro. As intervenções para os diagnósticos são sugeridas e podem ser escolhidas pelos enfermeiros estruturando-se o plano assistencial. Conclusão: Acredita-se que a inserção de uma tecnologia computacional à consulta de enfermagem traz inúmeras contribuições: padronização, integração com diferentes sistemas de informação e atualização permanente.

Descritores: Enfermagem; Consulta; Software; Hipertensão; Saúde.

\section{RESUMEN}

Objetivo: Informar sobre el desarrollo de un software para consulta de enfermería de los hipertensos en la Estrategia Salud de la Familia. Método: Investigación metodológica aplicada, basada en ingeniería de software de Pressman, desarrollada en tres ciclos: planeamiento, integrada por definición del prototipo y diseño del banco de datos; desarrollo de interfaz de navegación; y elaboración de expresiones funcionales y de programación. Resultado: el software posee pantallas administrativas y de consulta de enfermería. El historial permite realizar la primera consulta y/o las subsiguientes; el sistema sugiere los diagnósticos de enfermería una vez cargada la información, también el enfermero puede seleccionarlos. Las intervenciones para diagnósticos son sugeridas y pueden ser elegidas por los enfermeros, estructurándose el plan de atención. Conclusión: Se confía en que contar con un recurso informático para la consulta de enfermería brinde numerosas contribuciones: estandarización, integración con diferentes sistemas de información, y actualización permanente.

Descriptores: Enfermería; Consulta; Software; Hipertensión; Salud. 


\section{INTRODUCTION}

In the worldwide setting, advances in computer technology have provided changes in social, political, economic, and cultural relationships, work processes, and globalization of information. The healthcare area, as well as other knowledge areas, has suffered the influence of these changes, thus making care practice follow this evolution and modernize its way of providing care for human beings and their families.

Regarding systemic arterial hypertension (SAH) in Brazil, there is a strategic action plan (2011-2022) to fight chronic non-communicable diseases (NCDs), whose objective is to promote the development and implementation of effective, integrated, and sustainable policies based on evidence to prevent NCDs and their risk factors, treat them, and strengthen healthcare services, providing comprehensive care by means of the establishment of the Health Care Network (RAS, as per its acronym in Portuguese) $)^{(1)}$.

Many advances were made in the past decades, aiming at organizing and systematizing the care practice by means of the nursing process $(\mathrm{NP})_{{ }_{<0\}}}$ Therefore, resolution 358/2009 determined the implementation of the NP in all public and private healthcare services in which nursing care is required, with its five phases: nursing history; nursing diagnosis; nursing planning; implementation; and nursing evaluation. When carried out in healthcare institutions, ambulatory care facilities, homes, schools, and community associations, it is called nursing consultation (NC) ${ }^{(2)}$.

The use of the nursing process favored the establishment of nursing classification systems, among which the International Classification for Nursing Practice (ICNP $\left.{ }^{\circledR}\right)$ stands out, which gathers terms and concepts of diagnoses, results, and nursing interventions ${ }^{(3)}$. To facilitate the use of this classification during the execution and recording of the nursing process, the International Council of Nurses (ICN) has encouraged its introduction in information systems ${ }^{(4)}$.

Studies emphasize the contribution of the development of computer technologies in the healthcare area, such as electronic records of information and software development ${ }^{(5-9)}$. However, many countries, including Brazil, experience the challenge of connecting the diverse bodies of the Unified Health System (SUS, as per its acronym in Portuguese), so that care provided to users is carried out by the RAS ${ }^{(10)}$.

In this perspective, the Brazilian government launched in 2011, the National Health Plan (PNS, as per its acronym in Portuguese), which established goals for 2012-2015, with the aim of improving the SUS and providing the population with comprehensive and appropriate access to actions and good quality services. In addition to the plan, there are also the National Policy in Science, Technology, and Innovation in Health (PNCTIS, as per its acronym in Portuguese), the National Policy on Health Technology Management (PNGTS, as per its acronym in Portuguese), and the National Policy on Health Data and Information Technology (PNIIS, as per its acronym in Portuguese) $)^{(11)}$.

With the purpose of restructuring primary health care information at the national level, the government launched the e-SUS AB in 2013, which is an electronic information system of the primary health care, understanding that the qualification of information management is essential to improve the quality of care to the population. This strategy is the starting point for the qualified computerized information process in search for an electronic SUS ${ }^{(12)}$.

During the literature review of the present study, a gap was observed regarding the development of a nursing consultation software to hypertensive individuals. Therefore, the software developed in this study may contribute to improve the nursing consultation operationalization and standardization of nursing records, facilitate the information exchange among different levels of care, and spread knowledge, with the aim of improving the quality of care for hypertensive individuals and their families.

\section{OBJECTIVE}

To report the development of a nursing consultation software for hypertensive users of the Family Health Strategy (FHS).

\section{METHOD}

\section{Ethical aspects}

The development of the present study met standards and guidelines on research involving human beings, according to resolution no. 466/12 of the National Health Council (CNS, as per its acronym in Portuguese) $)^{(13)}$. The project was submitted to the research ethics committee of the Health Sciences Center of the Federal University of Paraíba-CCS/UFPB, approved and registered in the National Information on Human Research Ethics (SISNEP, as per its acronym in Portuguese), under protocol no. 0168/14.

\section{Study design, setting and period}

This was an applied methodological study carried out in the city of Cabedelo, from June 2014 to August 2015.

\section{Study population, inclusion and exclusion criteria}

An instrument developed and validated by the nurses of the family healthcare units of the city of Cabedelo was used for the development of the nursing consultation software for hypertensive users of the Family Health Strategy. Six nurses with clinical experience participated in this stage of the study. The inclusion criteria were: being a nurse; having experience in clinical practice in the care for hypertensive individuals in primary health care of at least five years; knowing and making use of $\mathrm{NC}$ and the ICNP ${ }^{\circledR}$.

\section{Study protocol}

The software was developed with the use of the International Classification for Nursing Practice to be used in the Family Health Strategy units located in Cabedelo, a city in the state of Paraíba, and which exclusively provides care to patients of the SUS. The software's development process was based on Roger Pressman's Software Engineering and grounded on the life cycle of development of systems; it begins with planning, made up of the definition phase of the database prototyping and modeling; development of the navigation interface; and elaboration of functional expressions and programming development. Then, it moves toward planning again to begin a new $\mathrm{cycle}^{(14)}$. 


\section{First cycle}

In the planning of activities, the necessary functions for the software were determined and, together with the programmer, the sequence of activities that the system should carry out was established, considering nursing consultation stages and possibilities of the program.

\section{Second cycle}

The structuring of the screens and development of the prototype was initially written, with the development of the navigation screens. Then, administrative screens (consultations, patients, category of indicators, indicators, diagnoses, interventions, and user registration) and other screens were developed for visualization of the history of consultations, patients who carried out consultations, new consultations, presentation of diagnoses and interventions, and exhibition of the care plan.

The next step was to convert the instrument of nursing consultation for hypertensive users of the FHS into simple screens that reflected the reality of care and kept the indicators and sequence of Horta's Human Basic Needs (HBN) present in the validated instrument. Other screens were used to present diagnoses, select interventions, and show the plan of care with choice of printing. Diagnoses and nursing interventions entered in the system were developed based on the ICNP ${ }^{\circledR}$ version 2013 and validated through a validation process by consensus of specialists with the six nurses of the FHS of the city of Cabedelo.

A prototype to illustrate the navigation interfaces of the system and their behavior was developed, in order to promote the interaction of nurses with the closest system (prototype) to the reality of care.

\section{Third cycle}

The objective of the development of functional expressions was the programming, based on the indicators present in the instruments of data collection, and guidance in the presentation of nursing diagnoses and interventions by the system.

\section{Data analysis}

The main technologies used for the development of the nursing consultation software for hypertensive users of the FHS were: the Ruby programming language, Ruby on Rails and Javascript; the adaptation of the responsive design through the use of the Bootstrap framework; the implementation of a production server, in which Ubuntu Linux and Nginx Web Server were executed; and the PostgreSQL's database management system. Ruby is a dynamic programming language, with a focus on simplicity and productivity. It has an elegant syntax, with natural reading and easy writing ${ }^{(15)}$.

\section{RESULTS}

The researcher and a professional from the IT area (programmer) participated in the software's development process. The programmer was in charge of matters regarding the knowledge of the software engineering, such as how to program the architecture of data input and output, and represent the data translated into the defined language, whereas the researcher was in charge of entering the clinical indicators based on Hortas' HBN, nursing diagnoses, results, and interventions of the ICNP ${ }^{\circledR}$ version 2013. This system was developed with free technologies.

The nursing consultation system for hypertensive users of the FHS, called SCEHAESF, is accessed through the link: www. icehaesf.bitmine.com.br. The initial screen of the system is shown in Figure 1. For access, the "user" name or "email" and password are required. Both pieces of information are registered by the system administrator. The following options are available: user registration, search for registered patients, visualization of consultations undertaken, undertaking of data collection, diagnoses, and nursing interventions registered in the system.

The screens were developed considering the sequence of human basic needs present in the validated instrument and phases of the nursing process. Figure 2 presents, as an example, part of the nursing history showing one of the categories of HBN - "need for vascular regulation".

The empirical indicators inserted in the screens of data collection were transferred from the nursing consultation instrument for hypertensive users of the FHS validated in a previous study ${ }^{(16)}$. The software was programmed so that new empirical indicators, new diagnoses, results, and nursing interventions can be included.

Fifty-four diagnoses and 220 nursing interventions were registered in the system, which were developed based on the International Classification for Nursing Practice and validated through a validation process by consensus of experts. Figure 3 presents the diagnoses suggested by the system after filling out the indicators.

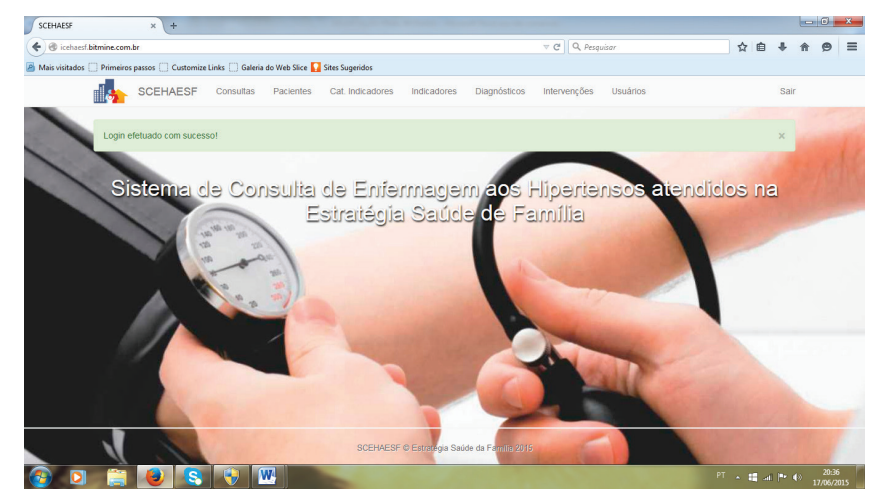

Figure 1 - Initial screen of the system, after login, João Pessoa, Paraíba, Brazil, 2015

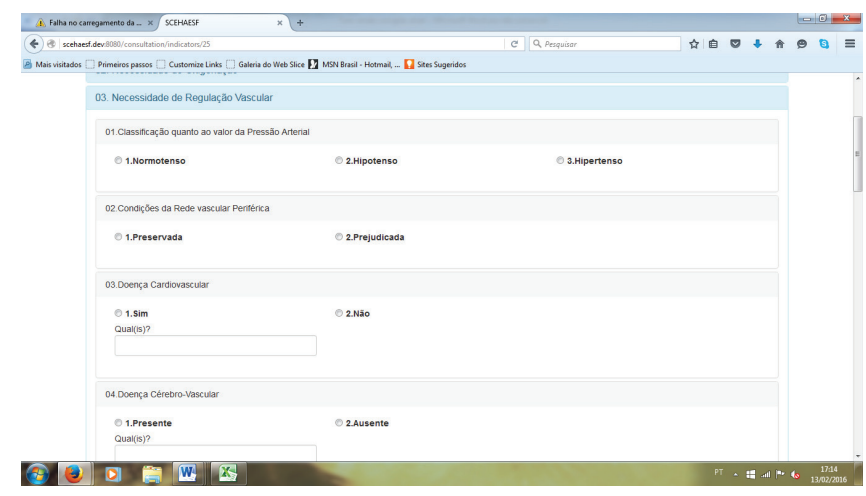

Figure 2 - Nursing history screen (need for vascular regulation), João Pessoa, Paraíba, Brazil, 2015 


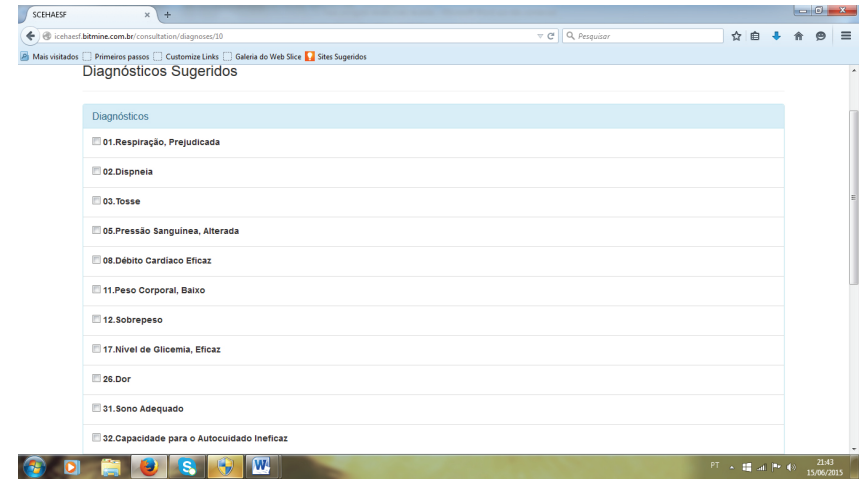

Figure 3 - Nursing diagnoses suggestion screen, João Pessoa, Paraíba, Brazil, 2015

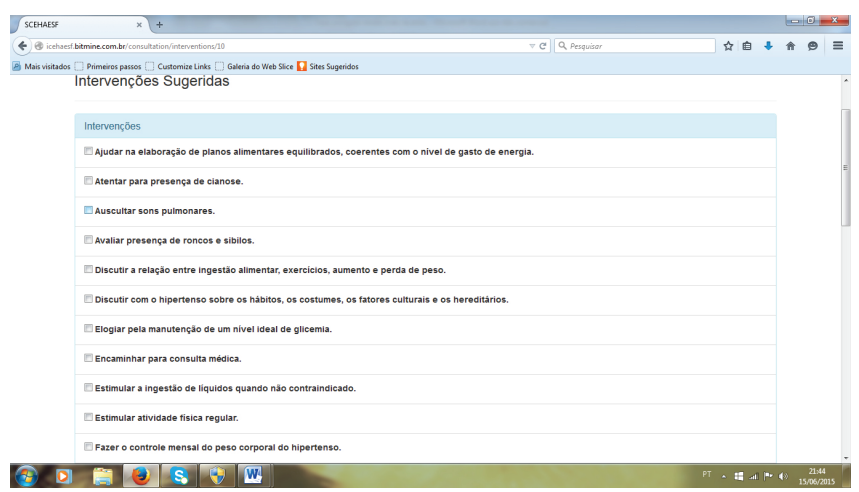

Figure 4 - Nursing interventions suggestion screen, João Pessoa, Paraíba, Brazil, 2015

Figure 4 presents the nursing interventions suggested by the system, according to nursing diagnoses selected. The system provides a list of nursing interventions linked to nursing diagnoses identified.

\section{DISCUSSION}

Software's development processes are complex and depend on people to take decisions and make judgments. There is no ideal process. Most organizations adapt the development processes of the software they use $\mathrm{e}^{(17)}$. Its quality depends on the project and the quality of the process ${ }^{(14)}$. The involvement of professionals who will use it is important so that a system can meet the demands of a service ${ }^{(18)}$.

Experts in quality "stated that the quality of a program is directly linked to the quality of the process used to create it". To achieve software quality, planning is necessary, making use of procedures, models, and standards, considering all stages of its life cycle with activities that aim to ensure the quality of the process and, consequently, contribute to improve the quality of the product ${ }^{(19)}$.

The use of computer tools in the healthcare area is increasing, especially due to technological innovations and what they can offer to professionals: collection of a larger amount of information, agility, storage, manipulation, and data recovery of each patient under the responsibility of healthcare professionals. In Brazil, the adoption of technological resources for nursing care is increasing since the 1960s, with the scientific basis of the profession ${ }^{(20)}$.

The implementation of computer tools integrated with electronic health records (EHRs) to document the NP is a gradual process and is in different implementation stages. Software development represents an advance for the nursing area due to the use of standardized systems of language and it will serve to demonstrate the nursing contribution to the health of individuals, enabling the measurement of both clinical effectiveness and cost of nursing care ${ }^{(21)}$.

A study ${ }^{(22)}$ showed that a computerized nursing process contributes to a more organized and faster work process for nurses, language standardization, and clarity in the recording of information. Knowledge coming from computer technology has supported and improved the nursing area ${ }^{(22)}$. Nurses recognize the importance of computers in their professional routine to significantly improve their practice ${ }^{(22-23)}$.

The use of software helps in the documentation of care actions, facilitating clinical judgment and the diagnostic reasoning process for both nursing professionals and students. It also contributes to evaluate diagnostic accuracy and improve the quality of care ${ }^{(11)}$. In addition, software enables nurses to check information of specific patients or data regarding all patients of the unit, or even of all patients of the institution, in fast and real time ${ }^{(24)}$.

The ICN recommends the use of the ICNP ${ }^{\circledR}$ in the care practice and its inclusion in information systems. Several studies have been carried out on this issue. The insertion of the International Classification for Nursing Practice in Collective Health (CIPESC, as per its acronym in Portuguese) in electronic records of FHS units in the city of Curitiba $^{(4)}$ can be mentioned as a pioneering example.

Nursing classifications entered into software contribute as a form of standardized and common language to be universally used by professionals in the planning of care, education, and research ${ }^{(3)}$. Having software or an application to record nursing consultations is an important advance for the profession. The information collected will not be lost in files and may be recovered for analysis. Therefore, nurses will have a significant amount of data to undertake their clinical reasoning and establish highly accurate diagnoses that reflect the actual clinical condition of individuals.

Computerized information systems are available resources that can improve, organize, and strengthen nursing care, in addition to manage nursing care indicators and provide any real-time data that nurses need to develop their actions ${ }^{(25)}$.

Therefore, it is important to consider that the nursing practice may achieve levels of excellence with the use of these technologies, which must be integrant elements in the context of care, as support tools for decision making, data collection, and generation of new information and knowledge ${ }^{(26)}$.

Consequently, nurses must be willing to know new technologies, participate in theoretical-practical training processes, and improve their practice with the use of computer technological tools applied to the care process in health.

\section{Study limitations}

The limitations of this study stand on the lack of familiarity of the FHS nurses with the nursing process and the ICNP ${ }^{\circledR}$ version 2013, and the need for testing the usability and quality of the system, since the tests were carried out through simulation.

\section{Contributions to the nursing area}

The introduction of computer technology in nursing consultation brings several contributions, such as the standardization 
and recording of nursing care and the optimization of the time used during nursing consultations, in addition to helping nurses in the planning, decision making, evaluation of the quality of care, dissemination of new knowledge, integration with different information systems, and continuous update.

\section{CONCLUSION}

The product of this study as a technological tool is expected to help FHS nurses and be used as a reference of care for hypertensive users of the primary health care network. In addition, there is the possibility of generating a database, with information that will enable the evaluation of hypertensive individuals from their first consultation and nursing care provided. The applicability of this technological tool is recommended in other regions.
As a contribution for education, the software may be used in the training of nurses, throughout the practical internships in primary health care, helping in the identification of diagnoses, results, and nursing interventions for hypertensive individuals during nursing consultations. The use of the software will generate data storage for future studies. Therefore, it is suggested that further studies on the development of nursing consultation software for specific users are carried out, such as diabetic patients, elderly people, children, and pregnant women, thus contributing to the work process of nurses.

In spite of the need for improving the current system, this is considered an advance in the care practice of nurses, since technological innovation for the documentation of nursing records is suggested, with the possibility of minimizing significantly errors and costs, promoting efficiency of information, reducing the length of time with manual documentation, and improving the quality of care.

\section{REFERENCES}

1. Brasil. Ministério da Saúde. Secretaria de Políticas de Saúde. Plano de Reorganização de Atenção à Hipertensão Arterial e ao Diabetes Mellitus[Internet]. Brasília, DF, 2014[cited 2014 Dec 13]. Available from: www.saude.gov.br

2. Conselho Federal de Enfermagem-Cofen. Resolução no 358 de 15 de outubro de 2009. Dispõe sobre a Sistematização da Assistência de Enfermagem, SAE e a implementação do Processo de Enfermagem em ambientes públicos ou privados, em que ocorre o cuidado profissional de Enfermagem e dá outras providências[Internet]. 2009[cited 2015 Aug 13]. Available from: http:// site.portalcofen.gov.br/node/4384

3. Clares JWB, Guedes MVC, Silva LF, Nóbrega MML, Freitas MC. Subset of nursing diagnoses for the elderly in Primary Health care. Rev Esc Enferm USP[Internet]. 2016[cited 2016 set 20];50(2):270-6. Available from: http//www.scielo.br/pdf/reeusp/v50n2/00806234reeusp-50-0272.pdf

4. Cubas MR, Albuquerque LM, Martins SK, Peruzo SA. Aplicação do inventário vocabular resultante do projeto CIPESC CIE ABEn nas unidade básicas de saúde do município de Curitiba-PR. In: Garcia TR, Egry EY. Integralidade da atenção no SUS e sistematização da assistência de enfermagem. Porto Alegre: Artmed; 2010.

5. Tannure MC, Lima APS, Oliveira CR, Lima SV, Chianca TCM. Nursing Process: comparison of manual versus electronic record. J Health Inform[Internet]. 2015[cited 2016 Oct 20];7(3):69-74. Available from: http://www.jhi-sbis.saude.ws/ojs-jhi/index.php/ jhi-sbis/article/download/337/235

6. Chianca TCM, Tannure MC, Salgado PO. Integração das classificações de enfermagem NANDA-I, NOC e NIC em sistemas de informação hospitalar. In: Herdman TH, Carvalho EC. PRONANDA. Ciclo 1. Porto Alegre: Artmed; 2013. p. 81-100.

7. Melo ECA, Enders BC. Construção de sistemas de informação para o processo de enfermagem: uma revisão integrativa. J Health Inform[Internet]. 2013[cited 2016 Jul 20];5(1):23-9. Available from: http// www.jhi-sbis.saude.ws

8. Labbadia LL, D'Innocenzo M, Fogliano RRF, Silva GEF, Queiroz RMRM, Carmagnani MIS, et al Computerized system for managing nursing care indicators at Hospital São Paulo. Rev Esc Enferm USP[Internet]. 2011[cited 2015 Nov 10];45 (4):1013-7. Available from: http://www.scielo.br/pdf/reeusp/v45n4/v45n4a32.pdf

9. Silva KL, Évora YDM, Cintra CSJ. Software development to support decision making in the selection of nursing diagnoses and interventions for children and adolescents. Rev Latino-Am Enfermagem[Internet]. 2015[cited 2016 Aug 25];23(5):927-35. Available from: http// www.scielo.br/pdf/rlae/v23n5/pt_0104-1169-rlae-23-05-00927.pdf

10. Metzger MM. The use of regional platforms for managing electronic health records for the production of regional public health indicators in France. BMC Med Inform Decis Mak[Internet]. 2012[cited 2016 Aug 25];3(12):28. Available from: http: //www. biomedcentral.com/1472-6947/12/28

11. Brasil. Ministério da Saúde. Secretaria-Executiva. Subsecretaria de Planejamento e Orçamento. Plano Nacional de Saúde - PNS: 2012-2015. Brasília: MS; 2011.

12. Brasil. Ministério da Saúde. Autoavaliação para Melhoria do Acesso e da Qualidade de Atenção Básica - AMAQ. Brasília: MS; 2013.

13. Brasil. Ministério da Saúde. Conselho Nacional de Saúde. Resolução no 466 de dezembro de 2012. Brasília: MS; 2012.

14. Pressman RS. Engenharia de software: uma abordagem profissional. 7a ed. Porto Alegre: AMGH; 2011.

15. Ruby. Ruby Language [Internet]. 2017[cited 2015 Sep 23]. Available from: https://www.ruby-lang.org/en/ 
16. Santana JS, Soares MJGO, Nóbrega MML. Instrumento de consulta para enfermería para hipertensos em salud de la familia: estúdio metodológico. O Braz J Nurs[Internet]. 2011[cited 2015 Sep 23];10(3):1-17. Available from: http// www.objnursing.uff.br/index. php/nursing/article/.../3481/1097

17. Sommerville I. Engenharia de Software. 9a ed. São Paulo: Person Prentice Hall; 2011.

18. Wong MC, Turner P, Yee KC. Involving clinicians in the development of an electronic clinical handover system - thinking systems not just technology. Stud Health Technol Inform[Internet]. 2008[cited 2015 Jun 16];136:490-5. Available from: http// www.ncbi. nlm.nih.gov/pubmed/18487779

19. Swebok. Guide to the Software Engineering Body of Knowledge: a project of the IEEE Computer Society Professional Practices Committee[Internet]. 2004[cited 2015 Jun 15]. Available from: http// www4.ncsu.edu/ tjmenzie/cs510/pdf/SWEBOKv3.pdf

20. Palomares MLE, Marques IR. Contribuições dos sistemas computacionais na implantação da sistematização da assistência de enfermagem. J Health Inform[Internet]. 2010[cited 2015 May 10];2(3):78-82. Available from: http// www.jhi-sbis.saude.ws/ojs-jhi/ index.php/jhi-sbis/article/download/94/34

21. Oliveira NB, Peres HHC. Evaluation of the functional performance and technical quality of an Electronic Documentation System of the Nursing Process. Rev Latino-Am Enfermagem[Internet]. 2015[cited 2015 Jun 15];23(2):242-9. Available from: http//www. scielo.br/pdf/rlae/v23n2/0104-1169-rlae-3562-2548.pdf

22. Lopes ACC, Ferreira AA, Fernandes JAL, Morita ABPS, Poveda VB, Souza AJS. Construction and evaluation of educational software on urinary indwelling catheters. Rev Esc Enferm USP[Internet]. 2011[cited 2016 Aug 15];45(1):215-22. Available from: http// www. scielo.br/pdf/reeusp/v45n1/30.pdf

23. Rezende LCM, Santos SR, Medeiros AL. Assessment of a prototype for the Systemization of Nursing Care on a mobile device. Rev Latino-Am Enfermagem[Internet]. 2016[cited 2016 Aug 15];24:2714. Available from: http// www.scielo.br/pdf/rlae/v24/01041169-rlae-24-02714.pdf

24. Assis MG, Assis MA, Amate FC. Software for mapping of the Pressure Ulcer, fall, and phlebitis. J Health Inform[Internet]. 2012[cited 2016 Jan 10];4(N.Esp):130-7. Available from: http// www.jhi-sbis.saude.ws/ojs-jhi/index.php/jhi-sbis/article/viewFile/243/138

25. Barra DCC, Sasso GTMD. Data standards, terminology and classification systems for caring in health and nursing. Rev Bras Enferm[Internet]. 2011[cited 2016 Mar 11];64(6):1141-9. Available from: http// http://www.scielo.br/pdf/reben/v64n6/v64n6a23.pdf

26. Santos SR. Computers in nursing: development of free software application with care and management. Rev Esc Enferm USP[Internet]. 2010[cited 2015 Jan 20];44(2):295-301. Available from: http://www.scielo.br/pdf/reeusp/v44n2/08.pdf 